\title{
Public Expenditures Through Public Procurement
}

\author{
Azem Duraku \\ PhD Cand. Department of Finance, Faculty of Economy, University of Tirana, Albania
}

\begin{abstract}
Treaty of Rome of 1957 and following treaties on amending the Treaty of Rome contain a number of basic principles on which the EU is founded. Among these principles, the most important ones related to the public procurement are: prevention of discrimination based on nationality, free movement of goods; right and freedom of establishment of a business; the right to provide services. Spending of public money in Kosovo pursuant to the Law on Procurement is found on the following principles: economization and efficiency; equal treatment and non-discrimination; transparency; value for money. The average of open procedure application in EU countries is $73 \%$ based on notices, whereas in Kosovo is $82.80 \%$ based on notices. In the end of 2014 , Kosovo commenced the development of electronic procurement platform. This project takes place within the Public Sector Modernization Project. The importance of the electronic procurement is stated in the statement of European Commission: "Modernization and opening of procurement markets across borders - including through the electronic procurement expansion - are crucial for the competition in Europe and creating new opportunities for businesses in EU". A good procurement system in Kosovo will have an impact on elimination of negative phenomena (corruption and bad management) in the management of public expenditures from spending agencies, as well as an impact on increase of budget saving.
\end{abstract}

Key words: public expenditures, value for money, bad management, procurement, electronic procurement.

\section{Introduction}

Public procurement in Kosovo started to appear shortly after the 1999 war. Considering the importance of a new area created in Kosovo, the United Nations Interim Administration Mission in Kosovo (UNMIK) prepared and formalized the first document on public procurement on 15 December 1999, known as the Financial Administrative Instruction no. 2/1999 on Public Procurement, through which, the rules on expenditures and funds of the Kosovo Consolidated Budget were established. Instruction no. 2/1999 is the second official document in Kosovo immediately after the Administrative Instruction no. 1/1999, which regulates the spending procedures of budget funds of the Kosovo Consolidated Budget.

These two documents, issued shortly after the war in Kosovo, have been the main basis for the implementation and management of all procurement activities for goods, labour and services, both in terms of procurement and financial aspects. FAI no. 2/1999 has been based on the procurement rules of the World Bank and the United Nations Commission on International Trade Law "UNCITRAL", the rules that have been used by most Central and Southeastern European countries during the transitional period.

Law on Public Procurement in Kosovo No. 2003/17 was promulgated by the SRSG on 9 February 2004, and entered into force on 9 June 2004. This law provides a far more comprehensive framework for public procurement in Kosovo compared to FAl no. 2/1999. The law, to a large extent, enables the increase of transparency in carrying out public procurement 
activities in Kosovo. The establishment of two central public procurement bodies foreseen by law for implementation of this law - the PPRC and the PPA - has been done with a considerable delay. There was a delay of three years, from the moment of finalization of the LPP by the working group appointed by the Government of Kosovo, in March 2003, until the full constitution of the institutions foreseen for the implementation of the law, in March 2006.

On 8 February 2007, the Assembly of Kosovo adopted the Law on Public Procurement in Kosovo, known as the Law No. 02/L-99. This amendment was signed and promulgated on 6 June 2007. The Law on Public Procurement No. 02/L-99 was followed by the establishment of three central procurement bodies in Kosovo: Public Procurement Regulatory Commission (PPRC); Public Procurement Agency (PPA); Procurement Review Body (PRB). There have been changes to the public procurement law and the public procurement rules that were intended to comply with the requirements of the EC Procurement Directives. Finally, the Law on Public Procurement No. 04/L-042 is in force, approved on 29 August 2011, which has finally been amended and supplemented with Law No. 05/L-092.

Kosovo started to develop the public procurement platform by the end of 2014. This project is funded by the World Bank, within the Public Sector Modernization Project. The Public Procurement Regulatory Commission (PPRC) is implementing the electronic procurement platform in Kosovo, where from the start of implementation as a pilot project in some contracting authorities, since January 2018, started the implementation of all procurement activities with a value over $€ 1000$ through through the electronic procurement platform by all Contracting Authorities that are obliged by law. The importance of eprocurement is highlighted in the modernization and opening of markets beyond borders, including through the expansion of e-procurement, which is crucial to competitiveness and creation of new business opportunities. Appropriate use of information technology contributes to cost reduction, improved efficiency, and removal of barriers to trade, which will ultimately lead to taxpayer money savings.

The main objectives to ensure a comprehensive increase are also focused on the social aspect: promoting employment and supporting the labour force movement; promoting social inclusion and combating poverty; investment in education, skills and lifelong learning; and enhancing institutional capacity and an efficient public administration. Public procurement is one of the market-based instruments that can be used to achieve the intended objectives in the future. Contracting authorities should use public procurement to advance these types of broader policy objectives.

\section{Research Methodology}

The study was carried out based on research in the field of public procurement that deals and analyzes with particular emphasis issues of this field, the applicable regulative for regulation of this field. During this research, I have used notes and publications from the official websites of CPA, PPRC, Ministry of Finance, Kosovo Agency of Statistics and other relevant institutions.

Unlike the cost-benefit analysis, the Comparative Cost-Effectiveness Analysis method is intended to determine alternative programs that, at a lower cost, ensure the achievement of the previously defined goal or the set of goals that are mutually complementary. The problem of selecting alternative programs can be divided into three ways: a) choosing the program that enables the achievement of the goal or some goals set at the lowest possible cost, b) choosing the program that, within limited financial means, to the greatest extent, enables the achievement of the goal or some goals set, and c) choosing the program that provides the most favorable ratio between the achievement of the goal or some goals and means committed.

\section{Public procurement activities in Kosovo during 2007 - 2016}

The following report presents the procurement activities for all contracts signed by contracting authorities, making an analysis of contracts signed between 2007 and 2016.

The signed contracts are presented with the division of contracting authorities into budget organizations - Government, Public Companies, and Other-NGOs. Based on this division, we will reflect the number of contracts signed as follows:

Table no. 1, Value of contracts signed during 2007 - 2016

The value of contracts signed during years, expressed in millions $€$

\begin{tabular}{|l|l|l|l|l|l|l|l|l|l|l|}
\hline Contracting Authorities: & 2007 & 2008 & 2009 & 2010 & 2011 & 2012 & 2013 & 2014 & 2015 & 2016 \\
\hline
\end{tabular}




\begin{tabular}{|l|l|l|l|l|l|l|l|l|l|l|}
\hline Governmental & $\begin{array}{l}187.4 \\
6\end{array}$ & $\begin{array}{l}456.6 \\
9\end{array}$ & $\begin{array}{l}529.8 \\
5\end{array}$ & $\begin{array}{l}286.7 \\
3\end{array}$ & $\begin{array}{l}284.7 \\
1\end{array}$ & $\begin{array}{l}318.5 \\
9\end{array}$ & $\begin{array}{l}348.6 \\
3\end{array}$ & $\begin{array}{l}259.6 \\
8\end{array}$ & $\begin{array}{l}250.2 \\
5\end{array}$ & $\begin{array}{l}359.7 \\
4\end{array}$ \\
\hline Public company & $\begin{array}{l}213.8 \\
2\end{array}$ & $\begin{array}{l}369.6 \\
2\end{array}$ & $\begin{array}{l}245.3 \\
8\end{array}$ & $\begin{array}{l}194.5 \\
7\end{array}$ & $\begin{array}{l}267.2 \\
6\end{array}$ & $\begin{array}{l}188.5 \\
6\end{array}$ & 93.62 & $\begin{array}{l}129.5 \\
7\end{array}$ & $\begin{array}{l}149.8 \\
1\end{array}$ & 62.06 \\
\hline Other/NGO & 0.94 & 0.16 & 2.92 & 0.75 & 0.17 & 0.70 & 1.92 & 0.47 & 1.77 & 2.76 \\
\hline Total1: & $\begin{array}{l}402.2 \\
2\end{array}$ & $\begin{array}{l}826.4 \\
8\end{array}$ & $\begin{array}{l}778.1 \\
5\end{array}$ & $\begin{array}{l}482.0 \\
6\end{array}$ & $\begin{array}{l}552.1 \\
5\end{array}$ & $\begin{array}{l}507.8 \\
6\end{array}$ & $\begin{array}{l}444.1 \\
8\end{array}$ & $\begin{array}{l}389.7 \\
3\end{array}$ & $\begin{array}{l}401.8 \\
4\end{array}$ & $\begin{array}{l}424.5 \\
7\end{array}$ \\
\hline
\end{tabular}

Source: Report on Public Procurement Activities for 2007 - 2016, PPRC.

The values of signed contracts are reflected from the data above, where it can be seen that Government Contracting Authorities have a higher value compared to public companies and other authorities. In the participation of the value of the contracts signed during 2016, Budgetary organizations - the Governmental ones participate with $84.73 \%$, public companies with $14.62 \%$, whereas other authorities participate with only $0.65 \%$ in the total value of signed contracts. If a comparison is made over the years, it can be seen that government-financed Institutions financed by the State Budget participate in the largest amount of signed public contracts in comparison with public companies and other authorities.

Table no. 2, Value of contracts signed by funding sources during 2007 - 2016

The value of contracts signed in years by funding sources, expressed in millions $€$

\begin{tabular}{|l|l|l|l|l|l|l|l|l|l|l|}
\hline Funding sources & 2007 & 2008 & 2009 & 2010 & 2011 & 2012 & 2013 & 2014 & 2015 & 2016 \\
\hline Own Source Revenues & $\begin{array}{l}145.8 \\
1\end{array}$ & $\begin{array}{l}145.2 \\
6\end{array}$ & $\begin{array}{l}178.9 \\
3\end{array}$ & $\begin{array}{l}149.5 \\
4\end{array}$ & $\begin{array}{l}222.2 \\
4\end{array}$ & $\begin{array}{l}188.5 \\
6\end{array}$ & 93.99 & 129.80 & $\begin{array}{l}147.4 \\
8\end{array}$ & 60.06 \\
\hline Kosovo Budget & $\begin{array}{l}250.1 \\
5\end{array}$ & $\begin{array}{l}676.5 \\
6\end{array}$ & $\begin{array}{l}586.5 \\
3\end{array}$ & $\begin{array}{l}326.2 \\
5\end{array}$ & $\begin{array}{l}323.8 \\
4\end{array}$ & $\begin{array}{l}314.1 \\
2\end{array}$ & $\begin{array}{l}343.4 \\
8\end{array}$ & 258.87 & $\begin{array}{l}251.0 \\
4\end{array}$ & $\begin{array}{l}352.0 \\
9\end{array}$ \\
\hline Donations & 6.25 & 4.65 & 12.67 & 6.27 & 6.06 & 5.17 & 6.7 & 1.05 & 3.31 & 12.41 \\
\hline Total: & $\begin{array}{l}402.2 \\
2\end{array}$ & $\begin{array}{l}826.4 \\
8\end{array}$ & $\begin{array}{l}778.1 \\
5\end{array}$ & $\begin{array}{l}482.0 \\
6\end{array}$ & $\begin{array}{l}552.1 \\
5\end{array}$ & $\begin{array}{l}507.8 \\
6\end{array}$ & $\begin{array}{l}444.1 \\
8\end{array}$ & 389.73 & $\begin{array}{l}401.8 \\
4\end{array}$ & $\begin{array}{l}424.5 \\
7\end{array}$ \\
\hline
\end{tabular}

Source: Report on Public Procurement Activities for 2007 - 2016, PPRC.

Based on the data above, it can be seen that the State Budget participates in the main part of funding sources in the financing of signed contracts, then own source revenues, and a part from donations. In 2016, there is a tendency of increase in the value of contracts signed by the sources of financing, the main part of the funding is part of the State Budget with $82.93 \%$, own source revenues participate with $14.15 \%$, whereas donations participate with $2.92 \%$. The supply contracts participate with $44.97 \%$. Service contracts with $16.88 \%$, contracts for design competitions with $0.12 \%$, while contracts for work participate with $41.03 \%$.

The trend of value increase in 2016 is because the value of Prishtina - Hani i Elezit Motorway foreseen for 2016 is added to it, in the amount of 155,97 mil $€$ where the value of work contracts during 2016 amounts to 330.19 mil $€$

The analysis of the structure or participation of the procedures implemented during 2016 indicates that the participation of the open procedure in the total value of the signed contracts is $84.55 \%$, which is one of the most used procedures and known as the most transparent. Also, participation of the negotiated procedure after publication of the contract notice is $0.04 \%$, and participation of the negotiated procedure without publishing the contract notice during 2016 is $11.76 \%$. The participation of procedures according to the price quotation is $2.39 \%$ and it participates with $0.66 \%$ according to the minimal

\footnotetext{
${ }^{1}$ Contract: Motorway Prishtina - Hani i Elezit, Street 6. For 2010, in the amount of 106.88 million $€$, for 2011, in the amount of 236.16 million $€$, for 2012 , in the amount of 235.37 million $€$, for 2013 , in the amount of 210.54 million $€$, for 2014 , in the amount of 55.46 mil $€$, for 2015 , in the amount of $€ 114.57$ mil, and for 2016, in the amount of $€ 155.98$ mil.
} 
value, limited with $0.52 \%$, whereas design competitions participate only with $0.08 \%$ in the value of total contracts signed in 2016.

Based on the analysis of the value of contracts signed in 2016, divided by contract award to a local and non-local economic operator, the total value of the signed contracts is $66.55 \%$ with the local operators registered in Kosovo. While from nonlocal operators, it is $33.45 \%$ in the total structure of signed contracts, where the value of 155.97 million $€$ relates to the contract of Prishtina-Hani i Elezit Motorway.

Chart 1, The average number of bidders competing for a tender during 2008 - 2016.

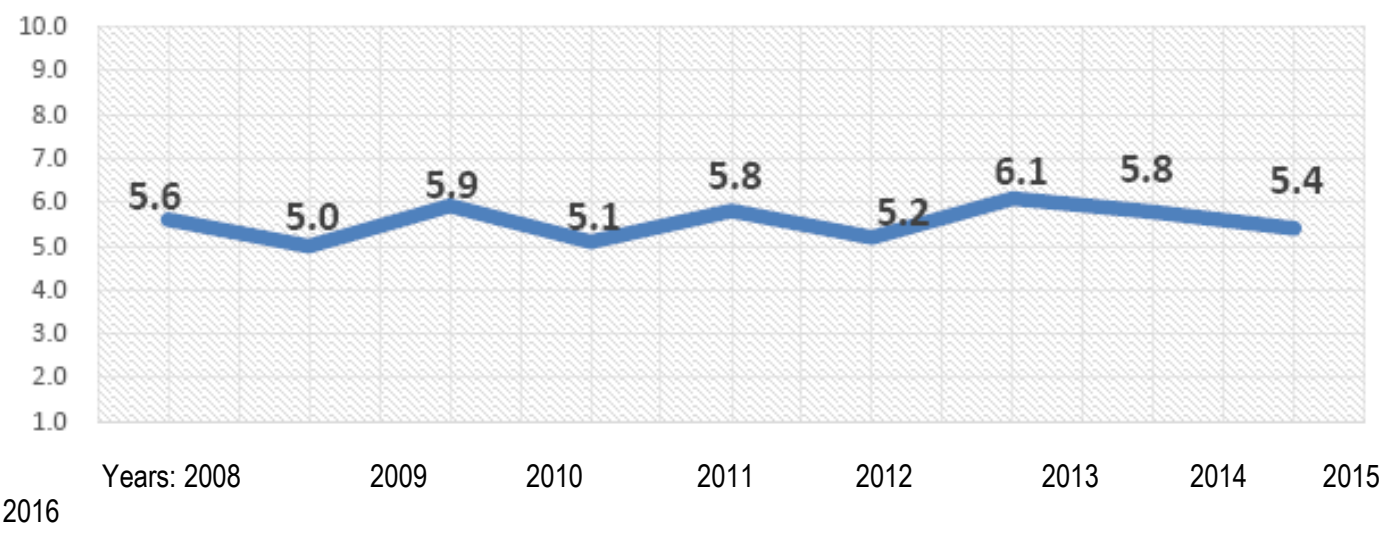

Chart No. 1 displays the average number of bidders who have competed for a procurement activity in Kosovo from 2008 to 2016. The average during these years shows that 5.5 economic operators have bid for a tender, which we think the principle of encouragement of competition is of an average level.

Chart 2 displays the value of contracts signed between 2010 and 2016

$900,000,000.00$

$800,000,000.00$

$700,000,000.00$

$600,000,000.00$

$500,000,000.00$

$400,000,000.00$

$300,000,000.00$

$200,000,000.00$

$100,000,000.00$

0.00

2016
$788,316,767.72$

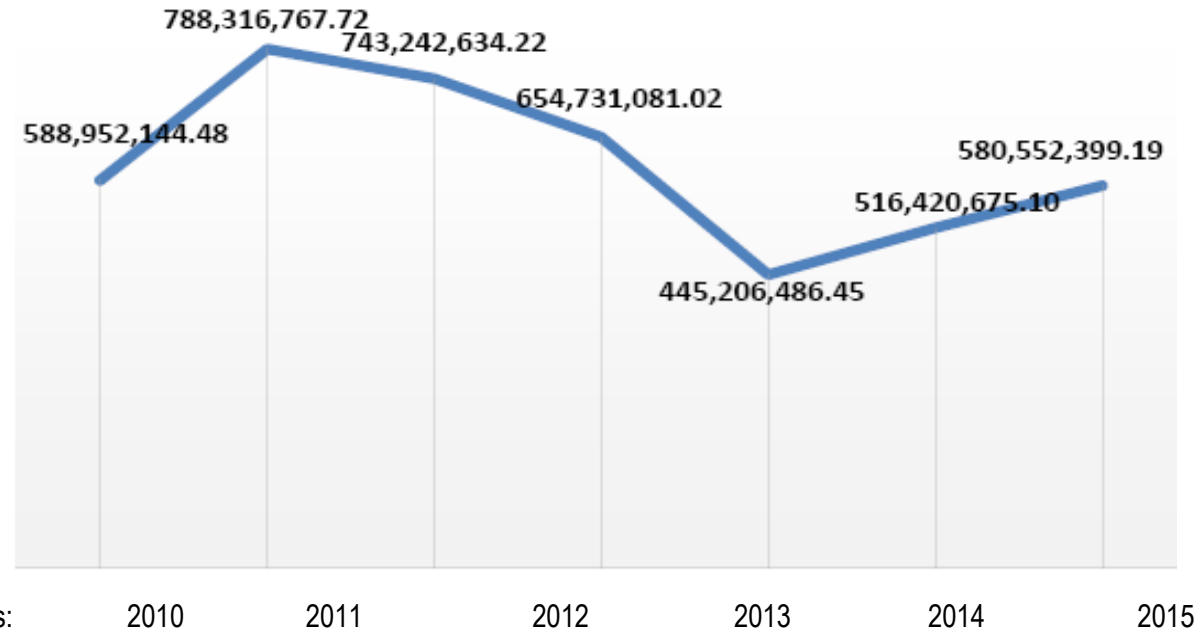


Chart No. 2 displays the value diagram of the contracts signed between 2010 and 2016, including two contracts with the highest value of motorway construction: 1. Morine - Merdar, and 2. Prishtina - Hani i Elezit. Also, in 2011, 2012, the value of contracts is higher because public companies have signed long-term contracts, and there has been higher spending on the Morine-Merdar Motorway project.

\section{Value of public procurement contracts in the Region}

Chart 3, Annual public procurement value in the region as a $\%$ of GDP

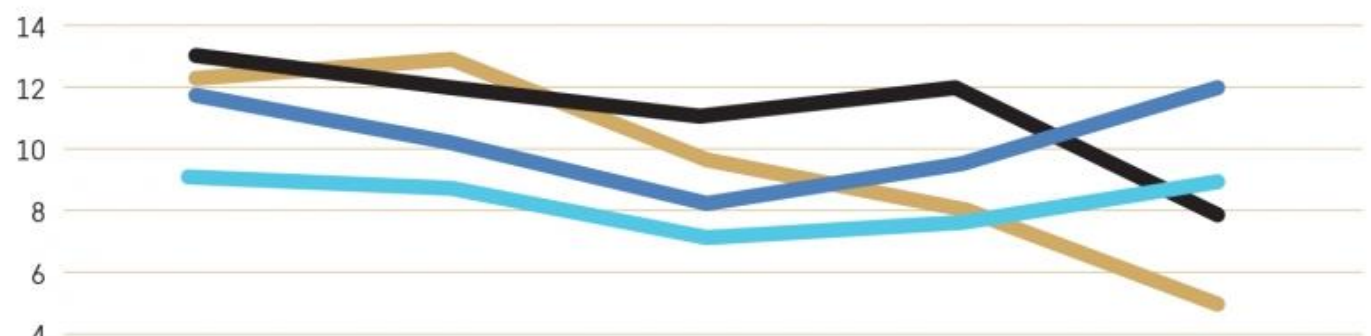

4

2

0

Years:

2011

2012

2013

2014

Source: Balkan tender watch 2016.

Herzegovina Serbia, $\rightleftharpoons$ Montenegro, Mosnia and

Public procurement is the process that public institutions pursue to carry out purchases of goods, services and works, mainly from the private sector. Public procurement is a significant part of the economy. At certain times, public procurement in Kosovo has reached the value of $1 / 5$ of GDP (Gross Domestic Product). Moreover, public procurement is a key process for ensuring responsible governance that supports a sustainable economic development.

However, the decrease in the proportion of public procurement contracts as a percentage of GDP is not necessarily an indicator of good state budget management. What makes public procurement successful is the strengthening of transparent practices. The biggest challenges for supporting transparency in public procurement arise from the fact that domestic (Kosovo and regional) institutions are mostly new in the fight against corruption. There is plenty of room for conflict of interest among politicians and businesses that contract with the government, and at the same time, there is a lack of technology integration in public procurement at central and local level.

The high value of public contracts executed through public procurement matters not only to get the best value for taxpayer money, but also to create an equitable environment where private companies can compete for these contracts. Consequently, the way this process is executed remains of particular importance.

The importance of public procurement can also be seen in terms of the amount of expenditure compared to the national budget and GDP or amount of government purchases. In Kosovo, public procurement of goods, services and works is about $9.4 \%$ of the GDP, for 2015 , the second largest expense after wages and salaries.

According to the 2014 Annual Audit Report, public institutions, through the procurement process, have spent about 488 million Euros, or about $33 \%$ of the Kosovo Budget expenses, a little higher than the average of OECD member countries during 2013, which was 29\% (see the chart below). According to the PPRC report, the value of contracts signed in 2015 was about 401 million Euros, excluding the value of the contract for the Prishtina - Han i Elezit motorway, the value of which 
reaches about 114 million Euros for 2015 (in total, about 516.4 million Euros). The public procurement market in 2014 accounts for $8.9 \%$ of the gross domestic product, which is a slight decrease compared to the previous three years, while lower than the OECD average in 2013 , which was $12.1 \%$.

These figures indicate that public procurement is vital to the country's economy and therefore, this very important public expenditure must be guided by a set of public principles, values, good practices, laws, regulations and procedures arising from a National Strategy of Public Procurement.

The modern public procurement system requires high standards of efficiency and transparency since public procurement is done for the public interest and it is a precondition for sustainable development, considering that it accounts for $33 \%$ of public expenses. The efficiency of the work of the bodies responsible for implementation of public procurement and the use of public funds is one of the principles of the Law on Public Procurement. On the other hand, transparency serves to inform the public, for access to legislation, policy and in carrying out procurement procedures by responsible institutions. One of the principles of Good governance requires the existence of central institutional and administrative capacity to develop implement and monitor procurement policy effectively and efficiently.

Therefore, the monitoring of the implementation of public procurement and institutional capacities is the main tool for assessing and increasing the efficiency of the functioning of the public procurement system. If carried out independently and professionally, monitoring can yield documented results on the weaknesses of the system and lead to useful suggestions and generalizations, taking into account the specifics of any known problem.

Monitoring requires sufficient capacities and appropriate organizational structure within the PPRC and a coordination between it and the CPA, PRB and other institutions responsible for implementing the procurement law.

Among the segments that directly affect the increase of efficiency in the work of public procurement bodies is coordination between central level institutions for public procurement work, centralized procurement, e-procurement, which also combine with the fulfilment of the principle of transparency in procurement.

Chart 4, The next diagram outlines overall government procurement as a percentage of total government spending (2013) for OECD countries (Government at a Glance 2015: Procurement Data, Paris, OECD, 2015, pg. 136.)

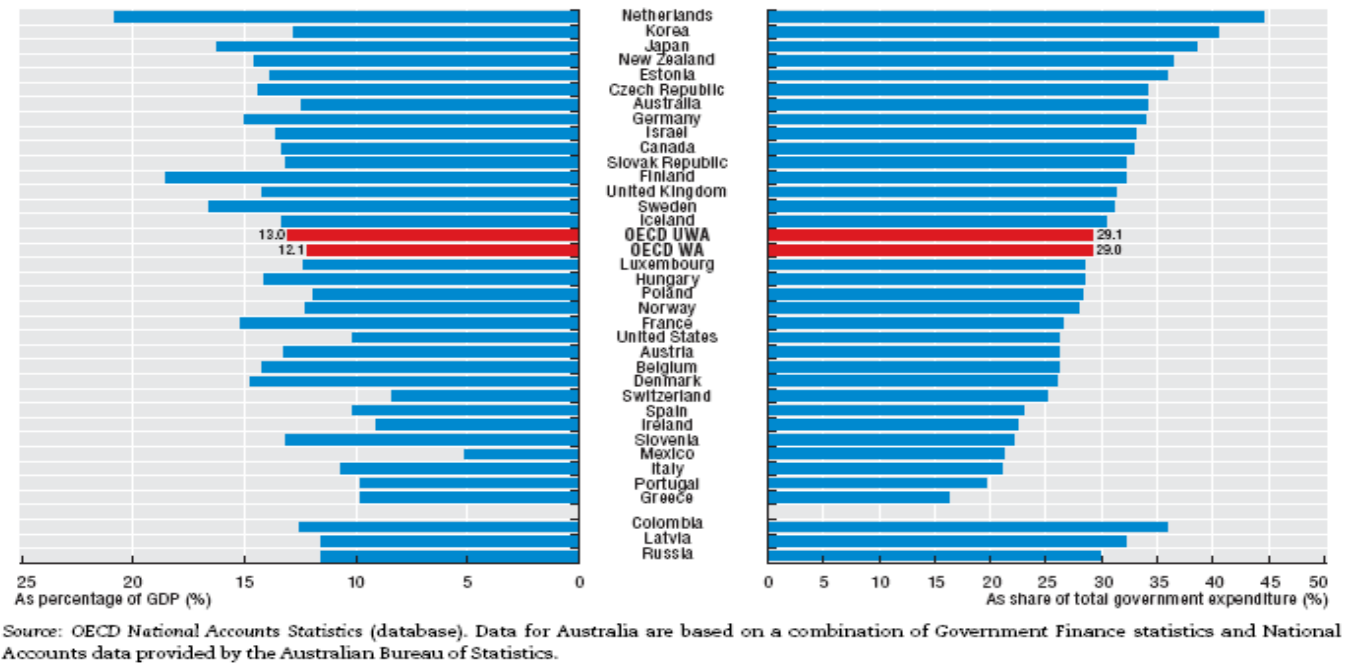

\section{Electronic Procurement in Kosovo}

The use of information technology for the public sector, and in particular the procurement system, is a driving force for increasing efficiency and effectiveness in the implementation of the procurement law. Electronic procurement will have multi-dimensional effects such as increasing transparency, preventing misuse, increasing competition and increasing 
accountability and confidence in implementing procurement procedures. Electronic procurement, amongst other things in the future, will also help facilitate monitoring as data on the performance of contracting authorities can be extracted from the system. But the challenge will be how electronic procurement can generate data and how much capacities exist at the PPRC, CPA, and contracting authorities in the management and use of the electronic system.

Kosovo has started by the end of 2014 to develop the e-procurement platform. This project is funded by the World Bank, within the Public Sector Modernization Project. The project application started at the end of 2014, where on behalf of the Government of Kosovo, the main beneficiary of this project is the PPRC, which will be the implementing institution of this project.

This project will contain:

- Development or adaptation, as well as the implementation of the procurement system from start to finish, transferring the ownership (source code) to the Government of Kosovo;

- The software package of the project will function as a complete system to assist the Government of Kosovo in conducting electronic procurement;

- The establishment of the Data Center will be done at the Ministry of Public Administration, with the same replication, as the second data center within the Ministry of Finance;

- Provide trainings for procurement staff, and hardware and software data that will be maintained by support staff;

- The e-procurement system will be prepared in three official languages in Kosovo: Albanian, Serbian, and English;

E-Procurement will complete all stages of the procurement process electronically, including these core modules:

- General Registration of Interested Operators, CAs, PPRC, CPA, PRB and other parties using the platform;

- Electronic bidding (from the procurement process planning, to the signing of the contract);

- Framework Agreements;

- Electronic auctions;

- Contract management;

- Procedures for handling complaints;

- Communication via electronic platform;

- Online Assistance.

In view of this, in January 2016, the Government of the Republic of Kosovo has begun to apply the electronic procurement system initially as a pilot in seven contracting authorities, including ministries, public companies and municipalities. Piloting has initiated the application in practice of the platform for a six month period in order to test the functionality of the system and will also serve as a Kosovo market test in response to the application of the e-procurement system. In March 2016 the Government decided that electronic procurement for centralized procurements should become mandatory from 1 April 2016, for central level budget organizations from 1 September 2016, and from 1 January 2017 electronic procurement has become mandatory for all budget organizations. A prerequisite for e-procurement readiness is the capacity building of procurement staff in e-Procurement. Therefore, the training plans will include training on electronic procurement.

Appropriate use of information technology contributes to cost reduction, improved efficiency and removal of barriers to trade, which will ultimately lead to taxpayer money savings. While technological aspects of procurement processes based on information technology (IT) are discussed infinitely, much less attention is paid to the impact on the organizational aspects and the one that is most relevant to the current discussion, the level of public procurement concentration.

Even if electronic procurement would be limited to the bidding process stage by using e-bidding, the fact that electronic procedures may be less costly than the document-based procedure leaves room for debate. Consequently, e-procurement solutions should make centralized procurement less advantageous, as each contracting authority would spend less resources by initiating its own electronic tendering procedure. However, such an argument ignores the technological choice 
behind the foundation of a simple electronic auction. In other words, there is no unique technology standard for organizing electronic auctions. Hence the more independent the local purchasing units are brought, the greater the chance that technological choices are not fully compatible, thus increasing the firm's costs to get familiar with different standards.

Since it is based on a single standard, a centralized procurement strategy would reduce these costs, thus promoting the participation of smaller firms in the procurement market, while all other factors should be equitable .In addition, concentration tends to increase the benefits of e-procurement. Purchasing of resources via the internet increases efficiency gains if procurement becomes more centralized, as such achievements would affect larger volumes of transactions and impact on a larger number of organizational structures.

\section{Contract management}

Contract management may be defined as the steps that enable the contracting authority and the economic operator to fulfill their obligations within the contract in order to achieve the objectives set out in the contract.

When a contracting authority agrees to a contract with an economic operator, the agreement cannot be left to move alone - it must be managed. Contracts are often complex and may involve many people, may take or last too long, and may consume many resources. It is therefore essential that they are managed properly.

The key to the process of successful contract management is the awareness that procurement officers should plan, do, check and operate. The "Plan, Do, Check, and Act" cycle (PDCA) was created by 1950s American theorist Edward Deming, who spent considerable time advising Japanese industry on overall quality management.

Regarding the procurement process, the "plan" phase of the Deming cycle refers to the phases preceding the award of the contract and the phase "do" refers to the activity of the economic operator over the duration of the contract. Many procurement officers are very careful during the "planning" phase, but then they leave the economic operator to "do" and forget to "check" and "act". In the context of the procurement, "check" refers to the verifications and controls involved to monitor performance, and "act" refers to the actions required to ensure that any performance that has run out of forecasts is brought back within the required parameters.

Efficient contract management is essential to the success of the contract. This includes the procurement officer and other interested parties in the contracting authority who work actively with the persons from the economic operator to achieve a supply in accordance with the agreed specifications.

Contracts with PDCAs that are not implemented actively have far fewer chances to be successful.

Contract management activities can be broadly grouped into three areas covering the "do", "check" and "act" phases of the PDCA. They are:

- Service supply management,

- Relationship management,

- Contract management.

Service Supply Management ensures that the service is provided according to the required level of performance and quality, as provided in the contract. Service Supply Management considers performance and manages the risk through the 'do', 'check' and 'act' steps of the PDCA. Includes setting up controls and agreements on the service level.

The relationship management aims to maintain the relationship between the economic operator and the open and constructive contracting authority, aiming at solving or relieving tensions and identifying potential problems at an early stage, while identifying opportunities for improvement. Relationships should be thoroughly professional throughout the 'do' phase of the PDCA, and should also include a professional approach to problem-solving and settlement of disputes.

Contract management addresses formal contract management and changes in documentation during contract lifespan. These areas of contract management ensure that the day-to-day implementation aspects of the contract are carried out efficiently and effectively. They can form activities related to any aspect of the PDCA.

Accountability is the central pillar of any public procurement system. Without transparent and accountable systems that enable institutions and citizens to engage with mutual accountability, large resources channeled through public procurement systems allow the risk of increased corruption and misuse of funds. Even in low-level corruption systems, 
public and civic oversight can help identify inefficiencies, thus increasing the efficiency and effectiveness of procurement in order to improve service delivery, where citizens benefit.

\section{Conclusions}

The essential elements required to ensure accountability are: a proper organization of state administration, access to public information, a system of control and balance between the powers, and an efficient internal administrative appeals system, as well as independent oversight and judicial review of administrative cases. Accountability should be supplemented with responsibility for the decisions of state institutions or their absence.

Budget implementation (executions) in Kosovo needs to be improved. Effective spending control is required at each stage of the budget cycle (ex-ante control, intern, external, etc.); adequate budget monitoring at each stage of the spending cycle (commitment, verification and payment); strengthening the internal control system (internal audit) in spending agencies.

A good procurement system in Kosovo will have an impact on the elimination of negative phenomena (corruption and mismanagement) in the management of public spending by spending agencies and will affect the increase of budget savings.

Other issues to be addressed in the coming period are:

- Procurement planning, a clear specification of each activity is required as well as their specification with the procurement plan and with the budget of the respective fiscal year, and other years if the activities have budgetary implications for more than one year period. The clear and complete specification of each activity that is expected to be implemented in the budget period should be followed with the provision of adequate budget funds approved by the respective levels. Adequate and timely specification of requests from the demanding units, especially the demand specifications but also the budget needed for realization is more than necessary.

- Strengthening of internal processes in the Contracting Authority starting from the requesting and approving units to the Procurement Department for the purpose of harmonizing the activities, especially at the stage of preparation of procurement planning. The challenge is that the requesting units do not submit their requests on time or submit them without specifying at the appropriate level, as they provide contradictory data for the necessary budget. Such a practice should be changed as soon as possible.

- Contract management - contract management and data implementation process, payments and other aspects of implementation remain one of the main challenges of the Public Procurement System, and relevant audit institutions will need to be more focused on this area in order to improve the part of contract management and their implementation.

- Organize further training related to contract management for the Contract Manager and technical and other staff involved in the implementation of the contract;

- Raise public awareness of the work that institutions do for implementing public procurement legislation and create citizens' trust in bodies implementing public procurement procedures. There is a perception among citizens that the public procurement sector has been exposed to abuse, corruption and mismanagement, which in many cases is also caused by the lack of activity of procurement bodies to inform citizens about achievements in the procurement system and raise awareness of citizens, businesses but also the staff responsible for the implementation of procurement procedures.

- Supporting small and medium Enterprises in public procurement activities without having demands, discriminatory criteria, but by promoting competition with special emphasis on new businesses;

- In addition to training of procurement officers from the field of public procurement, trainings should be organized for other parties, such as for managerial staff, for technical experts who prepare technical specifications for auditors and other parties that may be affected and give their input;

- The concept of e-learning can be considered as allowing an opportunity to improve professional skills and credentials through accessible online training. In addition, electronic teaching can be easily renewed (if designed appropriately) as the system grows and develops; 
- allowing the use of non-competitive negotiated procedures without the publication of a contract notice only in exceptional cases;

- Electronic Procurement is a procurement system that uses the opportunities created by the information and communication technology to increase the efficiency of the procurement process. The current size of paper on different levels of government should gradually be stored electronically on national and local databases for easy retrieval and usage when needed.

\section{Bibliography}

[1] Ministry of Finance: Medium Term Expenditure Framework 2016 -2018, Prishtina, 2015.

[2] Public Procurement Regulatory Commission: National Public Procurement Strategy 2015-2020, Prishtina, 2015.

[3] Ministry of Finance: Medium Term Expenditure Framework 2016 -2018, Prishtina, 2015.

[4] World Bank: Prequalification Document for Procurement of Works and User's Guide, Standard Procurement Document, 2007.

[5] World Bank, UNEP, IAPSO: Sustainable Procurement Training Package, 2004/2005.

[6] Sigma: Public Procurement Manual, 1996.

[7] Sigma: Training of Trainers in Public Procurement, 1999.

[8] Hoxha, S: Principles of Public Procurement, Prizren, 2016.

[9] Duli, I: Public Procurement in Kosovo, Pristina, 2008.

[10] Duli, I: Public Procurement of Kosovo - A decade and a half Prishtina, 2017.

[11] OECD: Government at a Glance 2015, OECD Publishing, Paris, 2015.

[12] PPRC: Reports on Public Procurement Activities in Kosovo for 2007-2016, Prishtina, 2016. 